FEATURE

Jim O'Donoghue

Office for National Statistics

\title{
The public sector balance sheet
}

- ach month, the Office for National

- Statistics (ONS) and HM Treasury

_ jointly publish statistics on the position of the public sector finances.

These attract considerable interest and frequent comment with particular attention being paid to the level of public sector net borrowing and net debt. The latter, in particular, has been affected by the classification of, first, Northern Rock (from October 2007) and subsequently Bradford \& Bingley (from September 2008) as public financial corporations.

At the date of its first inclusion, Northern Rock added around $£ 100$ billion to public sector net debt (PSND), while Bradford \& Bingley added a further $£ 50$ billion. Lloyds Banking Group and Royal Bank of Scotland (RBS) have been classified to the public sector with effect from October 2008. Data for these two banking groups have yet to be incorporated into the public sector finances but will have a significantly greater impact than Northern Rock and Bradford \& Bingley. ONS has estimated that this will add an additional $£ 1-1.5$ trillion to PSND (see ONS 2009).

The article will address issues raised by these banking groups coming into the public sector, clarifying how they are presented in the National Accounts and public sector finances and discussing the publication of more asset and liability detail than currently shown in public sector finances balance sheets.

The article then addresses the current relevance of PSND in the context of the banks now temporarily being classified inside the public sector boundary, with their very high levels of financial assets and liabilities. Alternative measures of debt are explained, and the definitions of public sector net debt and liquid assets are clarified.

With increased public focus on the public sector finances, some commentators have renewed their calls for a measure of debt including contingent liabilities, pension liabilities and all liabilities associated with private finance initiatives (PFI). The remainder of the article is taken up with discussion of the liability boundary for the National Accounts, business accounting, government accounting and the recommendations for presentation of non-PSND liabilities. Current practice for publication of these liabilities in the UK is then discussed.

\section{Sectorisation and asset and liability detail}

Sectoral classification of the public sector banks

RBS and Lloyds are financial services groups, each having hundreds of subsidiary companies. These subsidiaries are classified in many sub-sectors of the economy, including monetary financial institutions (MFIs), other financial institutions (for example securities dealers), insurance companies and non-financial corporations (NFCs). Their classification to the public sector, along with Northern Rock and Bradford \& Bingley, has caused some confusion about how this is reflected in the 
National Accounts, and the read-across to the public sector finances.

In the National Accounts, the subsectoral breakdown is by institutional sector (for example MFIs, insurance companies, and NFCs). The split into public and private sector is a secondary classification variable; it is not currently a legal requirement.

The NFC sector is presently the only one in the UK National Accounts that has a public/private split - the public part is called public corporations and, in practice, includes a few minor financial corporations. The public corporations sector in the National Accounts does not and will not include public sector banks or their financial subsidiaries: these continue to be classified to their primary National Accounts sectors. This means, for instance, that data for Northern Rock Bank is included within the overall MFI sector.

The situation is different for the public sector finances. Here, the public corporations sector includes Bank of England, Northern Rock, Bradford \& Bingley and their UK subsidiaries, as well as public NFCs (although in some presentations data for the public sector banks are shown separately from other public corporations). Data for Lloyds and RBS will be added into public corporations for the public sector finances as soon as is practicable, although they will remain classified to their existing sectors for the National Accounts. There are no plans to compile separate top-to-bottom accounts for each sub-sector of the National Accounts split by public/private corporations.

More detailed analyses of the public sector balance sheet

Before the classification to the public sector of Northern Rock and Bradford \& Bingley, it was possible to compile a full balance sheet for the public sector from the corresponding balance sheets for general government, public (nonfinancial) corporations and public financial corporations. Currently, it is not possible to do this because of concerns that commercially sensitive data may be disclosed by the publication of a detailed balance sheet for public financial corporations comprising a small number of banks.

These disclosure concerns exist because the difference in coverage of public corporations in the public sector finances and National Accounts means that, in principle, it is possible to deduce the public financial corporations element. This has severely limited the statistics that can be published in the public sector finances for public corporations including financial corporations. Indeed, the only balance sheet information that is used is the banks' contribution to public sector net debt.

With the further addition to the public sector of RBS and Lloyds Banking Group, it is anticipated that these disclosure concerns will lessen, and that it will be possible to start publishing more detailed information relating to transactions and balance sheet levels for financial assets and liabilities of public financial corporations. The precise level of detail will be determined in discussions which are on-going.

\section{Measures of public debt}

A key measure of the health of the public sector finances is the level of debt. There are several possible ways of measuring this. The most widely reported is public sector net debt, which is published monthly by ONS and HM Treasury and used domestically as part of the government's fiscal policy framework. However, there are a number of other measures of debt that are published by ONS or that can be derived from published figures.

This section explains how these, and other measures, are defined and highlights factors to be considered when interpreting the results. Particular attention is given to PSND because of the policy focus on it.

\section{Measures of debt}

There are several dimensions to measuring government and public sector debt:

- the sectors covered

- whether debt is measured consolidated or unconsolidated

- whether debt is measured gross or net of assets

- which liabilities or assets are included, and

- the basis of valuation

Each of these is considered in turn below.

The choice about which is the most appropriate depends on the particular need of the analyst.

The public sector comprises general government (central government and local government) and public corporations. Measures of debt are available for each of the sub-sectors, for general government, and for the public sector as a whole.

Consolidated measures of government debt remove central government holdings of local government debt, and vice versa. Similarly, consolidation for public sector measures removes all intra-public sector holdings of public sector debt.

Measures of debt are gross if they are calculated only from financial liabilities, or net if assets are fully or partially subtracted. Gross measures show the accumulated stock of borrowing. Some of this borrowing may have been incurred to purchase assets. Net measures of debt deduct the current value of assets held. These assets may be financial, such as lending to businesses, or non-financial, such as roads, schools and hospitals.

Commonly used net aggregates are net worth - total assets (financial plus non-financial) less total liabilities, and net financial assets - financial assets less financial liabilities.

The liabilities included in estimates of debt can cover some or all liabilities recognised by the National Accounts system. Similarly, net measures of debt may cover all assets (both financial and non-financial) or be limited to certain asset classes. Public sector net debt, as published in the Public Sector Finances Statistical Bulletin, includes most liabilities, but only 'liquid' financial assets.

In National Accounts based debt measures there are two options for valuing assets and liabilities - at nominal value or market value. For some classes of assets and liabilities, the two valuation bases are the same; examples are bank deposits and lending (although commercial accounting values loans at fair value). For others, where assets are traded and there is a market, such as government bonds, the two can differ. In the latter case, the nominal value shows the cost to the issuer of redeeming the bond when it matures; whereas the market value shows the current cost of going into the market to redeem the bond.

\section{Domestic measures of debt}

The main measures of debt published in the UK are:

- PSND, published monthly in the Public Sector Finances Statistical Bulletin. Measured at nominal values, consolidated, and calculated as liabilities less liquid assets. Financial Statistics Table 1.D shows how this is built up

- public sector net debt excluding the effect of financial sector interventions (PSNDX), for which quarterly data are published in the Public Sector Finances Statistical Bulletin. Similar to PSND but excluding the effect of classifying Northern Rock and Bradford \& Bingley 
to the public sector, along with the net cost of other interventions

- general government consolidated gross debt as calculated for the Maastricht Treaty's Excessive Deficit Procedure (see European Commission 1993). Measured at nominal values for the general government sector. The Excessive Deficit Procedure Statistical Bulletin shows the main components

- general government unconsolidated gross liabilities at market values, calculated in the National Accounts and published quarterly in UK Economic Accounts

- general government net financial liabilities at market values, calculated in the National Accounts and published quarterly in UK Economic Accounts, and

- general government net worth at market values, calculated in the National Accounts, and published annually in the National Accounts Blue Book

Figure 1 shows how the first five of these measures compare at the end of December 2008. General government net worth is not shown but the most recent figures for the end of 2007 show total assets (including non-financial assets) exceeding government liabilities by around $£ 350$ billion.

Figure 1 unsurprisingly shows that general government's gross unconsolidated financial liabilities at market prices are substantially higher than any of the other measures, but that if government's assets holdings are deducted the level of debt nearly halves, to become the lowest measure.

The effect of the financial sector interventions on the level of PSND can be clearly seen. At the end of December 2008, the effect of the classification to the public sector of, first, Northern Rock and subsequently Bradford \& Bingley had added around $£ 130$ billion to PSND.

The figure also shows that general government gross liabilities at market values are higher than the Excessive Deficit Procedure (EDP) measure at nominal values. In part, this is due to government bonds trading at values in excess of their nominal value. It also reflects differences in coverage, with the Excessive Deficit Procedure measure excluding accounts payable and differences due to the effect of consolidation.

\section{International comparisons}

International comparisons of debt are published by Eurostat, the International
Monetary Fund (IMF) and the

Organisation for Economic Co-operation and Development (OECD). They are usually based on central government or general government and are expressed as a percentage of gross domestic product (GDP).

Eurostat's data are based on the Excessive Deficit Procedure returns made by each Member State of the EU and relate to general government consolidated gross debt. The position at the end of December 2007 is shown in Figure 2. It can be seen that the UK, with debt at 44 per cent of GDP, is about midway in the ranking of countries and below the EU average.
Comparable figures for 2008 are available for the UK and show debt at 52 per cent of GDP, but are not yet available for other countries.

IMF and OECD measures of debt are based on National Accounts aggregates. OECD data for general government (not presented here) also show the UK ranking towards the middle, with gross financial liabilities a little below average and net liabilities a little above average. The OECD also present data for central government but care should be taken when using this as the remit of central and lower levels of government can vary between countries

\section{Figure 1 \\ Measures of debt at December 2008}

$\mathrm{f}$ billions, nominal values except where stated

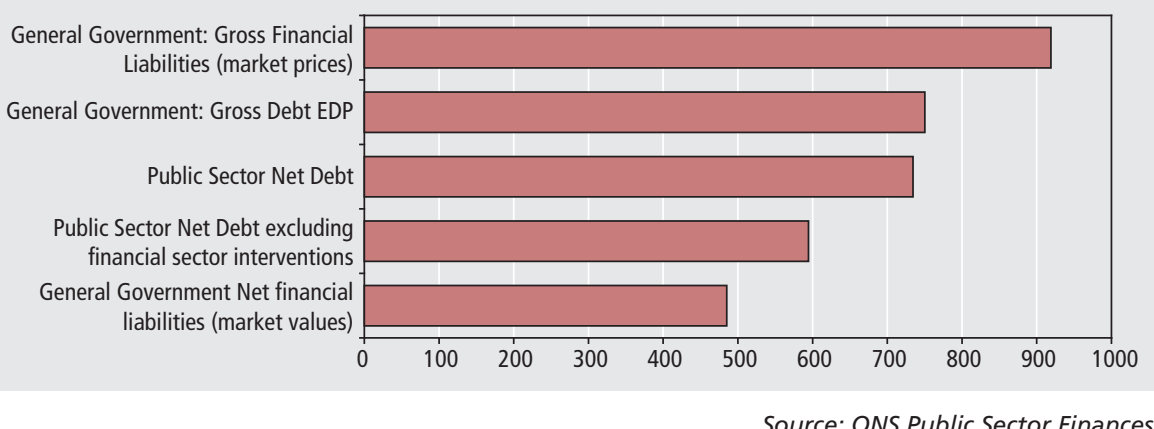

Figure 2

\section{Government gross debt in December 2007}

Percentage of GDP, Excessive Deficit Procedure basis

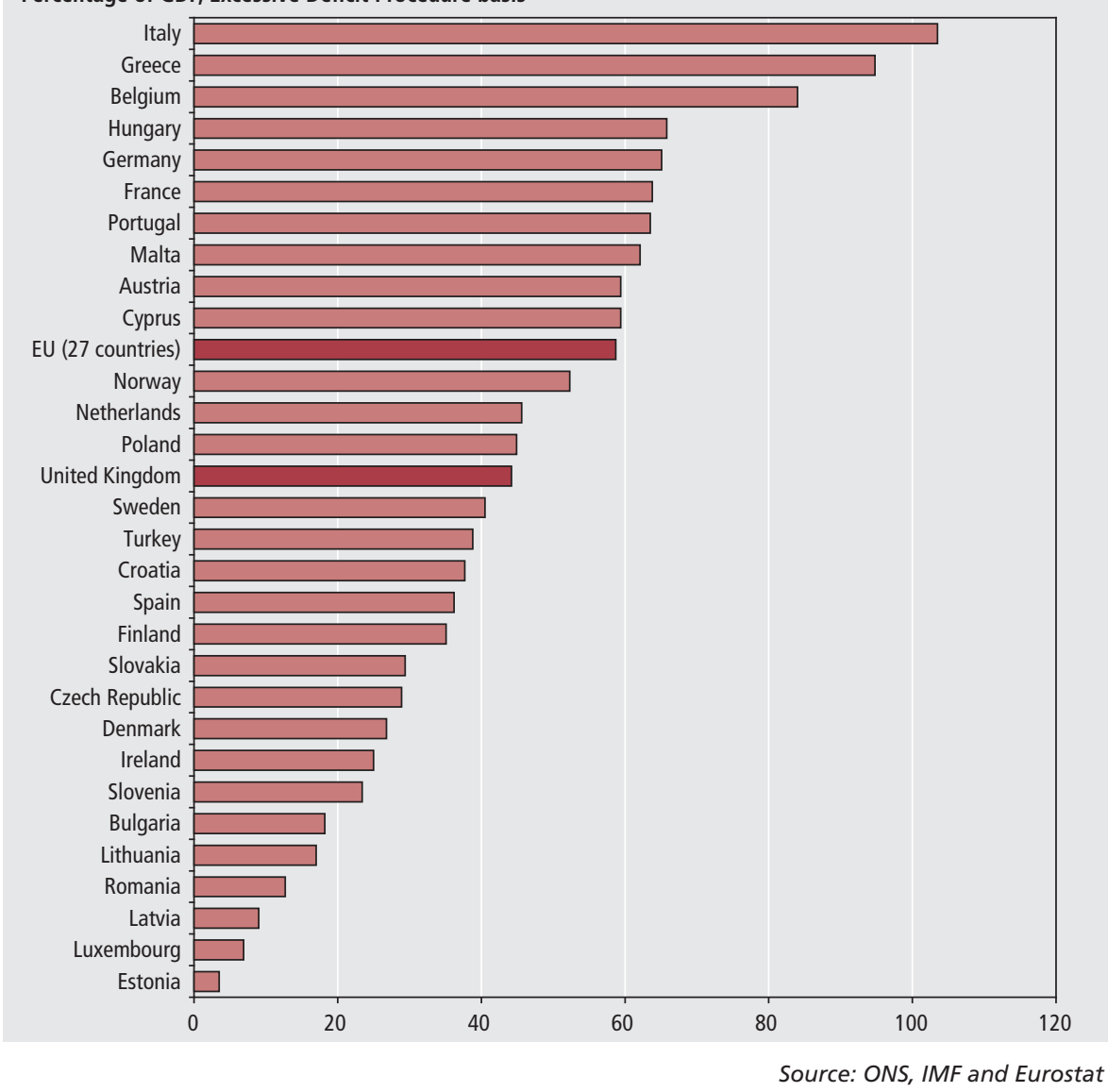


- for instance, the regional level of government in Germany has much greater powers than in the UK.

\section{PSND}

Measures of public sector debt have a long history in the UK. The current definition has been in use since the mid-1960s, and since 1997 has been a key statistic for assessing performance against the Government's fiscal rules. When the current administration came into power, it established two fiscal rules, including the sustainable investment rule which required that 'public sector net debt as a proportion of GDP will be held over the economic cycle at a stable and prudent level. Other things being equal, net debt will be maintained below 40 per cent of GDP over the economic cycle.'

The Pre-Budget Report (PBR) 2008 (see HM Treasury 2008) explained that:

'The Government will depart temporarily from the fiscal rules until the global shocks have worked their way through the economy in full. Consistent with the Code for Fiscal Stability, the Government is setting a temporary operating rule: to set policies to improve the cyclically-adjusted current budget each year, once the economy emerges from the downturn, so it reaches balance and debt is falling as a proportion of GDP once the global shocks have worked their way through the economy in full.'

The PBR 2008 also stated that 'while the public sector fiscal aggregates continue to be affected by interventions in the financial sector the Government will report on PSND both including and excluding the impact of those interventions.' The Economic and Fiscal Strategy Report (EFSR) 2009 (see HM Treasury 2009) provided further clarification:

'To ensure transparency in reporting on the impact of financial sector interventions on the public finances, the Government will publish information on three different bases:

- including financial sector interventions on a National Accounts basis: These measures reflect the treatment of financial sector interventions as determined by the National Accounts, including temporary and exceptional effects from, for example, the inclusion of the balance sheets and operations of banks classified to the public sector

- excluding liabilities and unrealised losses from financial sector interventions: These measures remove the temporary effects of financial sector interventions on the fiscal aggregates. As losses are realised for central government, and so can be reliably included in the fiscal projections, they will score in these measures, and

- including unrealised losses on financial sector interventions: These measures include the anticipated future loss stemming from the Government's financial sector interventions, and so are better measures of the sustainability of the medium-term fiscal position than those on the other two measurement bases. They remove the temporary effects of financial sector interventions on the fiscal aggregates'

Projections including a provisional estimate of future losses, that is on the third basis, were shown in the EFSR both for net borrowing and for net debt. In the monthly Public Sector Finance Statistical Bulletin net borrowing is shown only on the first of these bases and net debt only on the first two.

As described previously, PSND is defined as liabilities less liquid assets. The liabilities that contribute to PSND have traditionally been relatively well defined, in comparison to the assets, hinging on the interpretation of what constitutes a liquid financial asset. The expansion of the public sector to include public sector bank groups has prompted a need to define more clearly which classes of assets and liabilities are included in the calculation of PSND. The outcome of the resulting work, by a group comprising representatives from ONS, HM Treasury, and Communities and Local Government, is described in the following sections.

\section{Liquid assets - concepts}

The starting point for defining which assets should count in the calculation of PSND is to consider what is meant by liquid assets. Conceptually, a liquid asset can be thought of as one that is realisable at short notice without loss. This involves at least three main considerations, which are interrelated:

- capital certainty: whether the value of an asset is likely to change into the future. Factors that can influence this include:

- the credit-worthiness of the issuer: as a rule, debt issued by governments will be more certain of repayment than private corporations' debt, and

- the residual maturity of the asset: the shorter the time to the redemption date, the greater the certainty the debt will be repaid. In practice, information on residual maturity can be difficult to collect

- time: how quickly an asset can be disposed of (contrast a house with a treasury bill, or a timed deposit account)

- the market: note that conditions in the market might change and affect capital certainty and the time taken for an asset to be disposed of. For instance, the collapse in the market for residential mortgage backed securities has reduced the capital value of the assets and means that asset holders cannot realise their investments

Using these criteria, assets can be ranked according to a spectrum of liquidity; the dividing line between liquid and illiquid being in some sense arbitrary. For instance:
Notes and coins
Bank deposits
Treasury bills
Certificates of deposit
Government bonds
Short term commercial paper
Shares
Corporate bonds
Lending
Collateralised debt obligations (CDOs)

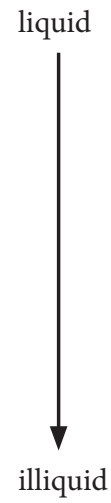

In this ranking, the assets at the top of the list clearly meet all three criteria for liquidity. This is not necessarily the case for those towards the bottom. For instance, loans are not marketable and cannot be readily realised (the borrower cannot be made to repay the loan). The exception to this is short-term inter-bank lending which is recorded as bank deposits. In the case of quoted shares, there is usually a market, but their value (capital certainty) cannot be guaranteed.

\section{Liquid assets - in practice}

As noted before, bank and building society deposits, and notes and coins are clearly liquid. Other classes of assets that are judged to be liquid are public sector short- 
term holdings of private sector and rest of the world securities, where short-term is defined as those assets with an original maturity of up to one year. (Conceptually, residual maturity may be better but this is difficult to obtain in practice.)

Because PSND is a consolidated measure, assets that are liabilities of other public sector bodies are also deducted when calculating net debt for the public sector as a whole.

A further class of assets are also considered to be liquid. In general, liquidity is an attribute of the asset and not of the holder. The exception to this are assets held by central government funds involved in debt and reserves management, in particular the official reserves and the Debt Management Office (DMO), and assets held by the Bank of England.

The official reserves include the Government's holdings of gold, special drawing rights and foreign currency securities. These assets need to be highly liquid so that they can be made available quickly for intervention purposes (or other permitted uses) if necessary. By convention, therefore, securities that form part of the official reserves are treated as liquid assets when measuring net debt, regardless of their original maturity.

The DMO's role includes making arrangements for funding and for placing central government's net cash positions, to ensure that sufficient funds are always available to meet any net daily cash shortfall and, on any day when there is a net cash surplus, to ensure this is used to best advantage.

Assets held by the Bank of England (including long-term securities) are also treated as liquid, reflecting the Bank's role in the money markets. In the particular case of long-term securities, which are not normally treated as liquid assets, the Bank keeps them as reserves that can be sold at any time or are actively traded assets (mainly foreign bonds).

\section{Financial instruments counting towards net debt}

Table 1 summarises the assets and liabilities counting towards PSND, classified according to the European System of Accounts (ESA) 1995 financial instruments

\section{Specific issues}

The work on the technical definition of PSND considered a number of specific issues that are described as follows.

\section{Recording of derivatives}

The recording of derivatives has not been a major concern until recently because they have not been widely used by public sector bodies. The inclusion of banks within the public sector changes this. For instance, RBS's latest publicly available results show derivatives with values approaching $£ 500$ billion on both sides of the balance sheet.

International guidance (ESA 1995 and the System of National Accounts (SNA) 1993) recommends that derivatives should be treated as financial assets. Also, Eurostat's Manual of Government Debt and Deficit notes that derivatives do not have a nominal value identical to that of other debt instruments. They also have limited capital certainty. For these reasons, it has been decided that they should be excluded from the calculation of net debt. The exceptions to this are the official reserves and the Bank

Table 1

Financial assets and liabilities counting towards PSND

\begin{tabular}{|c|c|c|c|c|c|}
\hline & & \multirow{2}{*}{\multicolumn{2}{|c|}{$\begin{array}{c}\text { Bank of England, Official } \\
\text { Reserves } \\
\text { Debt Management Agency }\end{array}$}} & \multirow{2}{*}{\multicolumn{2}{|c|}{ Other public sector bodies }} \\
\hline & & & & & \\
\hline \multicolumn{2}{|c|}{ ESA code } & Liabilities & Assets & Liabilities & Assets \\
\hline F.1 & Monetary gold and SDRs ${ }^{1}$ & $\mathrm{x}$ & & & \\
\hline F.21 & Currency & $\mathrm{X}$ & $x$ & & $x$ \\
\hline F.22 & Transferable deposits & $x$ & $x$ & $x$ & $x$ \\
\hline F.29 & Other deposits ${ }^{2}$ & $x$ & $x$ & $x$ & $x$ \\
\hline F.331 & Short term money market instruments & $\mathrm{x}$ & $x$ & $x$ & $x$ \\
\hline F.332 & Bonds & $\mathrm{X}$ & $x$ & $x$ & \\
\hline F.34 & Financial derivatives & $\mathrm{x}$ & $x$ & $x$ & \\
\hline F.4 & Lending & $\mathrm{X}$ & $x$ & $x$ & \\
\hline F.5 & Shares & $x$ & $x$ & $x$ & \\
\hline F.6 & Insurance technical reserves & & & & \\
\hline F.7 & Accounts receivable/payable & $\mathrm{X}$ & $x$ & & \\
\hline
\end{tabular}

Notes:

Source: ONS Public Sector Finances

1 Special Drawing Rights.

2 Short-term lending of up to a year between monetary financial institutions (MFI) is classified as deposits, as are reverse repos with monetary financial institutions, and investments in money market funds.

of England's holdings of derivatives, which are recorded as assets, reflecting the two organisations' roles in managing liquidity operations.

\section{Insurance companies}

The classification of RBS and Lloyds to the public sector also brings their subsidiaries into the public sector, including insurance companies. This raises the question of how insurance companies' liabilities and assets should be treated in the calculation of the public sector net cash requirement (PSNCR) and net debt.

The vast majority of insurance companies' liabilities are their technical reserves. This represents their liabilities to policy holders in the form of prepayments of premiums, and reserves against outstanding claims; the latter representing the present value of the amounts expected to be paid out in settlement of claims. It has been decided that insurance technical reserves should not count towards net debt on the grounds that:

- for other public sector bodies, credits such as prepayments do not count towards public sector net debt, and

- reserves against outstanding claims are very different in nature to other liabilities that currently count towards net debt, in that they are an assessment of future liabilities, unlike bank borrowing or debt securities, which represent current liabilities

It has also been decided that insurance companies' assets should not count towards net debt. To do so, would distort net debt as the corresponding liabilities are not included.

\section{Externally managed funds}

Local authorities place surplus funds or reserves with external fund managers. There are two types of funds - money market funds and other managed funds. The treatment of these funds was last considered in 1993, when it was concluded that both should be treated in full as liquid assets. This was primarily on the grounds that it was not possible to 'look through' the funds to see where the fund manager had actually placed them, and that local authorities viewed these funds as essentially being liquid assets.

However, while there is still no asset breakdown of money market funds (they are treated as F.2 deposits in the National Accounts), a breakdown of the underlying assets is available for other managed funds and is used for their recording in the 
National Accounts. It has been decided that:

- money market funds should continue to be treated as liquid assets, and

- for other externally managed funds, the characteristics of the underlying assets should be used to determine which are liquid. This approach will also be applied more widely to other managed funds, such as those held by the Nuclear Liabilities Fund

\section{Interpreting PSND}

The level of PSND is published monthly in the Public Sector Finances Statistical Bulletin, while net debt excluding financial sector interventions is published quarterly. In the period up to September 2007, before the classification of Northern Rock to the public sector, the level of PSND largely reflected central government's net debt, as shown in Table 2.

This situation has started to change. By the end of December 2008, the classification to the public sector of, first, Northern Rock and subsequently Bradford \& Bingley had added around $£ 130$ billion to PSND.

When the Lloyds Banking Group and RBS are included in the public sector finances, ONS has estimated that this will add an additional $£ 1-1.5$ trillion to PSND.

However, this statistic needs to be treated with caution. The way in which PSND is defined means that illiquid assets held by these banks - in the form of lending to businesses; for mortgages and holdings of corporate bonds - are not taken into account. This is important because the

Table 2

Breakdown of public sector net debt in September 2007

$\mathrm{f}$ billions

Central government debt, net of holdings by local government and public corporations Local government debt, net of holdings by central government and public corporations

Public corporations debt, net of holdings by central government and local government

Central government liquid assets

Local government liquid assets

Public corporations liquid assets

Bank of England net debt

Public sector net debt

Source: ONS Public Sector Finances

banks' liabilities are generally matched by their assets. What PSND shows is the extent to which the public sector's liabilities are matched by assets which can be realised quickly.

The effect on PSND of classifying these banks to the public sector should not be interpreted as meaning that the Government (and by implication the taxpayer) has been saddled with a substantially greater debt burden. The Government has also made clear its intention to return these banks to the private sector, so in the long run the impact on PSND is unlikely to be permanent.

\section{Conclusion and recommendations}

ONS, the Bank of England and HM

Treasury are working closely with RBS and the Lloyds Banking Group to correctly classify all subsidiaries of the two groups and then incorporate the relevant data into the public sector finances. Work is also ongoing to resolve disclosure issues so that more asset and liability detail can be published, in the interests of transparency.

\section{CONTACT}

《 시r@ons.gsi.gov.uk

\section{REFERENCES}

European Commission (1993) 'Council regulation (EC) No 3605/93 of 22 November 1993 on the application of the Protocol on the excessive deficit procedure annexed to the Treaty establishing the European Community'

HM Treasury (2008) ' Pre-Budget Report', available at:

www.hm-treasury.gov.uk/prebud_pbr08_ index.htm

HM Treasury (2009) 'Economic and Fiscal Strategy Report', Chapter 1 of the 2009

Budget Report, available at: www.hm-treasury.gov.uk/bud_bud09_index. htm

ONS (2009) 'News Release (19th February 2009) - Classification of Royal Bank of Scotland Group PLC and Lloyds Banking Group PLC', available at: www.statistics.gov.uk/pdfdir/crbslbg0209.pdf 